\title{
Antibacterial and Corrosion Resistance Properties of Anodized AA6061 Aluminum Alloy
}

\author{
Nattapon Pornnumpa ${ }^{1,2}$ and Manthana Jariyaboon ${ }^{2,3, *}$ \\ 1 Materials Science and Engineering Program, Faculty of Science, Mahidol University, Bangkok 10400, \\ Thailand \\ 2 Center for Surface Science and Engineering, Faculty of Science, Mahidol University, Nakhon Pathom \\ 73170, Thailand \\ 3 Department of Chemistry, Faculty of Science, Mahidol University, Bangkok 10400, Thailand \\ *E-mail: manthana.jar@mahidol.ac.th (Corresponding author)
}

\begin{abstract}
Anodizing is one of the surface treatments for aluminum and its alloys. It is commonly used to increase corrosion resistance and mechanical properties. This technique is also applied for decorative purpose. Therefore, anodized aluminum alloys are widely used in many applications such as household structure, cell-phone case, automobile and aircrafts. Anodic aluminum oxide (AAO) structure, which has a pore at the center of each hexagonal cell arrangement, is created after anodizing process. To further enhance the property of anodized aluminum alloys, antibacterial property can be produced on AAO surface by deposition of nanoparticles into its pore structure. In this work, AA6061-T6 aluminum alloy was anodized at $12 \mathrm{~V}$ using $20 \% \mathrm{w} / \mathrm{v} \mathrm{H}_{2} \mathrm{SO}_{4}$ at temperature of $17 \pm 1^{\circ} \mathrm{C}$ for 30 minutes. $\mathrm{AgNO}_{3}$ solution was used for producing $\mathrm{Ag}$ nanoparticles. Effects of $\mathrm{AgNO}_{3}$ concentrations on antibacterial and corrosion resistance properties of anodized AA6061 aluminum alloy were studied. Antibacterial property was investigated on both gram-positive (S.aureus) and gram-negative (E.coli) bacteria according to JIS Z 2801 standard test for three months after exposure to ambient environment. 100\% reduction of S.aureus was achieved, whereas $97.3 \%$ reduction of E.coli was obtained when using $1 \mathrm{mM} \mathrm{AgNO}$. However, the deposition of Ag nanoparticles resulted in a slight increase in corrosion susceptibility.
\end{abstract}

Keywords: Anodized aluminum, antibacterial, corrosion.

ENGINEERING JOURNAL Volume 23 Issue 4

Received 3 May 2019

Accepted 10 June 2019

Published 8 August 2019

Online at http://www.engj.org/

DOI:10.4186/ej.2019.23.4.171 


\section{Introduction}

AA6061 is an aluminum alloy containing magnesium and silicon as major alloying elements. Because of its alloying elements, AA6061 shows good corrosion resistance, machinability, weldability and good anodizing response. It is extensively used in many applications such as household structure, cell-phone case and automobile [1-3]. Although AA6061 has good corrosion resistance, corrosion problem still occurs due to intermetallic particles in the alloy. Therefore, several surface treatments are commonly used to protect the alloy from corrosion attack. Anodizing is one of them. Anodizing process creates anodic aluminum oxide (AAO) film on the surface via electrochemical reactions. The anodic aluminum oxide film is composed of two layers that are inner barrier layer and outer porous layer. The inner barrier layer plays an important role on corrosion resistance because of its compact dense structure. The outer porous layer is hexagonal cell arrangement having single cylindrical pore at the center of each cell resulting in its absorption property $[4,5]$. Thus, several properties can be improved after anodizing process such as good interface adhesion, good surface appearance, improvement of mechanical as well as anti-corrosive properties [6,7]. However, accumulation of microorganism on the surface can still emerge on some areas, where the proper cleaning cannot be reached leading to biocorrosion problem.

Biocorrosion correlates with microorganism on the metal surface, especially bacteria. Bacteria can attach and agglomerate on the surface to form biofilm causing suitable conditions for corrosion. Inside the biofilm, there are many bacterial colonies that live in, which excrete metabolic waste and change environment underneath the biofilm [8]. Hence, the prevention of bacterial attachment on the surface can reduce biocorrosion attack.

Silver nanoparticles (AgNPs) are well known as one of the antibacterial agents because they can prevent in broad spectrum of both gram-positive and gram-negative bacteria. They were reported that they could kill even fungi, yeast, as well as virus [9]. Hence, there are many products using AgNPs as antibacterial agents such as disinfectant for wound cleaning, laundry machine and clothes [10]. So, it is interesting to develop anodized aluminum alloy surface enhanced with antibacterial property by deposition AgNPs into the anodic aluminum oxide film.

In general, anodizing process has three significant steps. The first step is surface preparation to control quality of the surface. The second step is anodizing to create anodic oxide film and the last step is sealing process to close up oxide pores. In order to obtain the anodized aluminum surface with antibacterial property, four main methods have been patented [11-14]. (i) Electrodepositing antibacterial metals into the porous surface layer of anodized aluminum [11]; this method is cheap, simple and fast; however color of the anodized aluminum produced from this method may be limited by metals used in electrodeposition process. (ii) Coating organo-silane layer with antibacterial property on the anodized aluminum surface [12]; this method is time and energy-consuming process since several steps of heat treatments must be applied to obtain organo-silane layer. (iii) In-situ thermal reduction [13]; cations (i.e., $\mathrm{Ag}^{+}$) in solution are thermally reduced to obtain nanoparticles with antibacterial property and at the same time they are deposited into porous layer during sealing step of anodizing process. Drawback of the in-situ thermal reduction method is that the temperature used to synthesizing nanoparticles must be the same as those used in the sealing step. (iv) Soaking anodized aluminum into a suspension mixture containing nanoparticles with antibacterial performance and sealing agent [14]; this method provides pore sealing layer distributed with nanoparticles. The precise control of size of nanoparticles in the suspension is needed and aggregation of nanoparticles must be avoided.

In this work, we have proposed a new method to overcome the mentioned drawbacks. In-situ chemical reduction was used to produce and deposit silver nanoparticles simultaneously into the porous layer of anodized AA6061-T6. This process was carried out before the sealing step of anodizing process. Effects of silver nitrate concentrations used to synthesize silver nanoparticles on antibacterial and corrosion resistance properties of anodized AA6061-T6 were investigated. 


\section{Experimental}

\subsection{Material}

AA6061-T6 sheet with a thickness of $1 \mathrm{~mm}$ was used in this work. It was purchased from C-line limited Partnership, Thailand. The chemical composition of this alloy was shown in Table 1. Specimens were cut into dimensions of $50 \times 50 \times 1 \mathrm{~mm}^{3}$ and $30 \times 30 \times 1 \mathrm{~mm}^{3}$ for antibacterial and electrochemical tests, respectively.

Table 1. The chemical composition of AA6061-T6 (wt\%) [3].

\begin{tabular}{llllllllll}
\hline Alloy & $\mathbf{S i}$ & $\mathbf{F e}$ & $\mathbf{C u}$ & $\mathbf{M n}$ & $\mathbf{M g}$ & $\mathbf{C r}$ & $\mathbf{Z n}$ & $\mathbf{T i}$ & $\mathbf{A l}$ \\
\hline $6061-\mathrm{T} 6$ & $0.4-0.8$ & 0.7 & $0.15-0.40$ & 0.15 & $0.8-1.2$ & $0.04-0.0 .35$ & 0.25 & 0.15 & Balanced \\
\hline
\end{tabular}

\subsection{Synthesis of Silver Nanoparticles (AgNPs)}

Silver nanoparticles (AgNPs) were synthesized by in-situ chemical reduction. Silver nitrate $\left(\mathrm{AgNO}_{3}\right)$ solution was reduced by $0.1 \% \mathrm{w} / \mathrm{v}$ trisodium citrate $\left(\mathrm{Na}_{3} \mathrm{C}_{6} \mathrm{H}_{5} \mathrm{O}_{7}\right)$ at $96 \pm 1^{\circ} \mathrm{C}$. Volume ratio of $\mathrm{AgNO}_{3}$ solution to trisodium citrate was 10 to 1 [15]. The concentrations of $\mathrm{AgNO}_{3}$ solution used in this work were $0.5 \mathrm{mM}$ and $1 \mathrm{mM}$.

\subsection{Anodizing Process and Deposition of Silver Nanoparticles (AgNPs)}

AA6061-T6 sheet was ground using $\mathrm{SiC}$ paper upto 1200 grit no. It was then put in $8 \% \mathrm{w} / \mathrm{v} \mathrm{NaOH}$ followed by $6 \% \mathrm{w} / \mathrm{v} \mathrm{HNO}_{3}$ for etching and desmutting, respectively. It was anodized in $20 \% \mathrm{w} / \mathrm{v} \mathrm{H}_{2} \mathrm{SO}_{4}$ at $12 \mathrm{~V}$ with a temperature of $17 \pm 1^{\circ} \mathrm{C}$ for 30 minutes. AgNPs were deposited into the anodic aluminum oxide film after the oxide film was created by dipping the specimen into silver nitrate solution as described in Section 2.2. Finally, it was sealed by soaking in boiled water at temperature of $96^{\circ} \mathrm{C}$ for 25 minutes. Figure 1 illustrates a method of how to produce the anodized AA6061-T6 with antibacterial property.

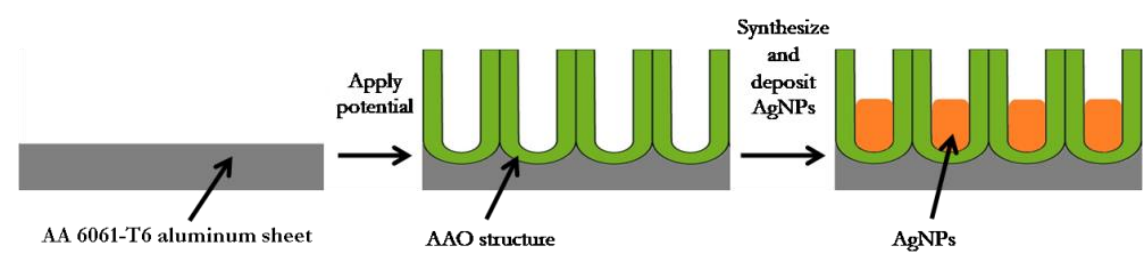

Fig. 1. Schematic diagram showing a method of fabrication anodized AA6061-T6 with antibacterial property.

\subsection{Antibacterial Standard Test}

Antibacterial performances of the anodized AA6061-T6 without and with AgNPs deposition were investigated monthly according to JIS Z 2801 standard test [16] for three months after exposing to environment as illustrated in Fig. 2. E.coli and S.aureus bacteria were used as gram-negative and gram-positive bacteria, respectively.

The specimens were sterized by UV-exposing for 30 minutes on each side before testing, after that bacteria were inoculated on the surfaces. Incubation was performed by an incubator (Daihan Labtech CO., LTD, Model LIB- $060 \mathrm{M}$ ) at $37^{\circ} \mathrm{C}$ for 24 hrs. After incubation, the bacteria on the surfaces were extracted and diluted to make 10-fold serial dilutions. Each dilution was spreaded on a new petri dish containing nutrient agar and it was then incubated at $37^{\circ} \mathrm{C}$ for $24 \mathrm{hrs}$ again. Bacterial colonies having the number of colonies in a range of 30-300 colonies were counted to determine viable cells per $\mathrm{cm}^{2}$, colony forming unit per $\mathrm{cm}^{2}$ $\left(\mathrm{CFU} / \mathrm{cm}^{2}\right)$, according to Eq. (1).

$$
N=\frac{C \times D \times V}{A}
$$


where $\mathrm{N}=$ number of viable cells (per $1 \mathrm{~cm}^{2}$ of test piece)

$\mathrm{C}=$ number of colonies $(\mathrm{CFU})$

$\mathrm{D}=$ dilution factor

$\mathrm{V}=$ volume of broth used to wash out

$\mathrm{A}=$ surface area of covering film $\left(\mathrm{cm}^{2}\right)$

$\mathrm{CFU} / \mathrm{cm}^{2}$ was used to calculate antibacterial activity and percent reduction of bacteria as shown in Eq. (2) and (3), respectively.

$$
\mathrm{R}=\left(\mathrm{U}_{t}-U_{0}\right)-\left(A_{t}-U_{0}\right)=U_{t}-A_{t}
$$

where $\mathrm{R}=$ antibacterial activity

$\mathrm{U}_{\mathrm{o}}=$ average of logarithm numbers of viable bacteria immediately after inoculation on untreated specimens

$\mathrm{U}_{\mathrm{t}}=$ average of logarithm numbers of viable bacteria after inoculation on untreated specimens after 24 hrs

$A_{t}=$ average of logarithm numbers of viable bacteria after inoculation on antibacterial treated specimens after $24 \mathrm{hrs}$

$$
\% \text { reduction }=(\mathrm{A}-U) / U \times 100
$$

where $\mathrm{A}=$ average value of viable bacteria after inoculation on antibacterial treated specimens after $24 \mathrm{hrs}$

$\mathrm{U}=$ average value of viable bacteria after inoculation on untreated specimens after $24 \mathrm{hrs}$

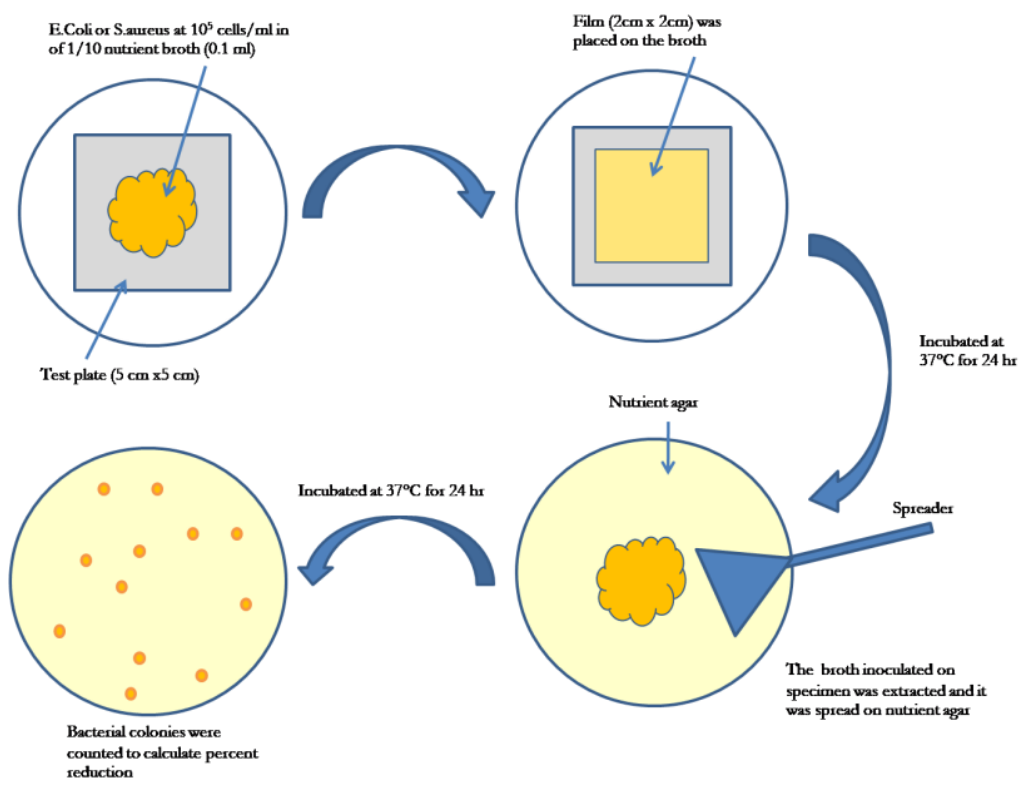

Fig. 2. Schematic diagram of JIS Z 2801 standard test.

\subsection{Electrochemical Test}

To measure potentiodynamic polarization curves, a three-electrode system was used with an Autolab (PGSTAT302N) potentiostat. Reference and counter electrodes were a saturated $\mathrm{Ag} / \mathrm{AgCl}$ and a platinum rod, respectively. AA6061-T6 with an exposure area of $1 \mathrm{~cm}^{2}$ was a working electrode. The potentiodynamic polarization curves were scanned with a scan rate of $1 \mathrm{mV} / \mathrm{s}$ in naturally aerated $3.5 \% \mathrm{w} / \mathrm{v} \mathrm{NaCl}$ solution. Measurements were performed in triplicate. 


\subsection{Microstructural Characterization}

Microstructures of the anodized AA6061-T6 were investigated using field emission scanning electron microscopy (FE-SEM, FEI - Versa 3D Dual Beam) equipped with energy dispersive X-ray spectroscopy (EDS, EDAX/Oxford Instruments). Specimens were coated with gold. FE-SEM/EDS was operated at 20 $\mathrm{kV}$.

\section{Results and Discussion}

\subsection{Macroscopic Appearance of the Anodized AA6061-T6}

Macroscopic images of the anodized AA6061-T6 without and with AgNPs deposition were shown in Fig. 3. As seen in Fig. 3, matte surfaces with unique texture were obtained for both cases due to the anodic aluminum oxide film structure. Color of the anodized AA6061-T6 without AgNPs was grey. In case of those with AgNPs, slight yellow shade appeared on the surface due to the color of AgNPs. Therefore, AgNPs were deposited on the anodized AA6061-T6 without significant effect on decorative application.

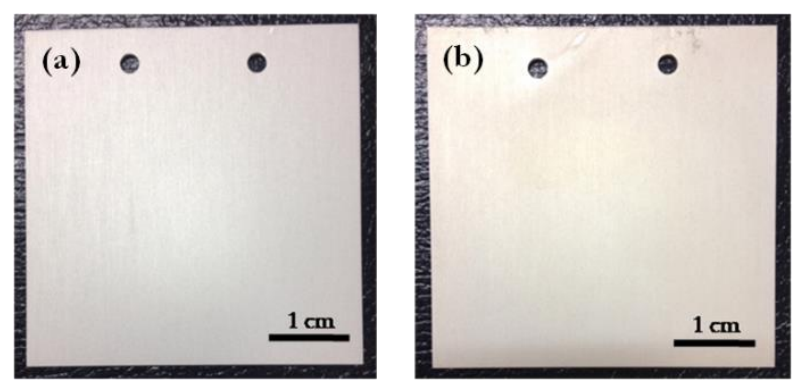

Fig. 3. Macroscopic images of the anodized AA6061-T6. (a) without AgNPs and (b) with AgNPs deposition.

\subsection{Microstructure of the Anodized AA6061-T6}

Top-view FE-SEM images at 100,000 magnifications of the anodized AA6061-T6 without and with AgNPs deposition synthesized using $0.5 \mathrm{mM}$ and $1.0 \mathrm{mM} \mathrm{AgNO}_{3}$ are illustrated in Fig. 4. In case of without AgNPs deposition $(0 \mathrm{mM} \mathrm{AgNO}$ ), there were unsealed and sealed areas on the anodic oxide film layer of the anodized AA6061-T6 as displayed in Fig. 4(a). After deposition of AgNPs, the microstructure was changed as displayed in Fig. 4(b) and (c). The surfaces showed more sealed areas. However, "discrete uncovered area", which was quite deep, was observed in black color. Increase in $\mathrm{AgNO}_{3}$ concentrations reduced "the discrete uncovered area". In addition, it should be noted that the structure of anodic oxide film (cross-section view) could not be seen even at high magnification FE-SEM. The thickness of the anodic oxide film for all conditions was approximately $12 \mu \mathrm{m}$.
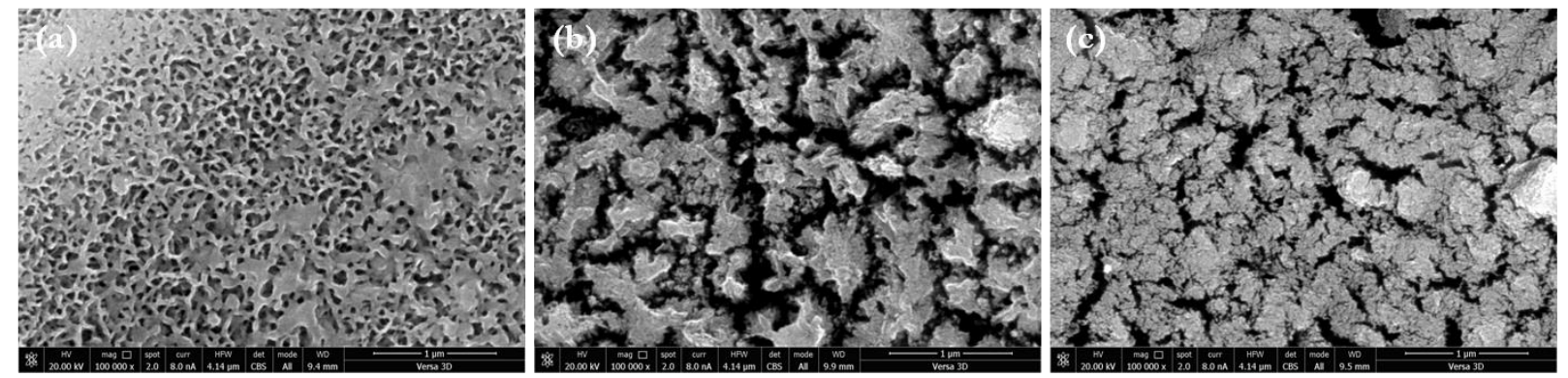

Fig. 4. Top-view FE-SEM images of the anodized AA6061-T6 at 100,000 magnifications. (a) $0 \mathrm{mM} \mathrm{AgNO} 3$, (b) $0.5 \mathrm{mM} \mathrm{AgNO}_{3}$ and (c) $1 \mathrm{mM} \mathrm{AgNO}$. 
Figures 5 and 6 show EDS point analysis and EDS mapping analysis of cross-section FE-SEM images of the anodized AA6061-T6 with AgNPs deposition synthesized using $0.5 \mathrm{mM}$ and $1 \mathrm{mM} \mathrm{AgNO}_{3}$, respectively. AgNPs were found near the surface of the anodic oxide film. AgNPs with a size of approximately $6 \mu \mathrm{m}$ were seen as illustrated in Fig. 6 indicating agglomeration of silver nanoparticles. In addition, it should be pointed out that AgNPs could not be detected by EDS analysis on the top-view of the surface. This is very surprising, since $100 \%$ antibacterial efficiency was achieved as reported in section 3.3.
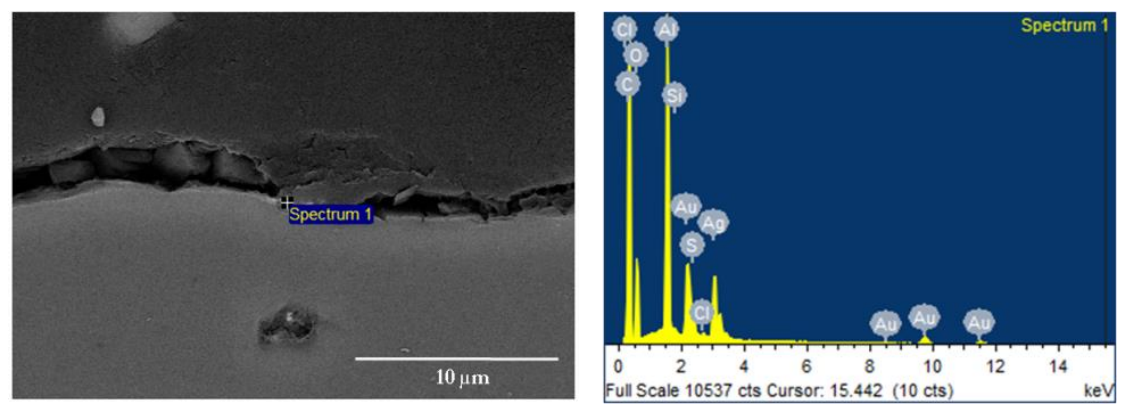

Fig. 5. EDS point analysis of the anodized AA6061-T6 with AgNPs deposition synthesized using $0.5 \mathrm{mM}$ $\mathrm{AgNO}_{3}$.
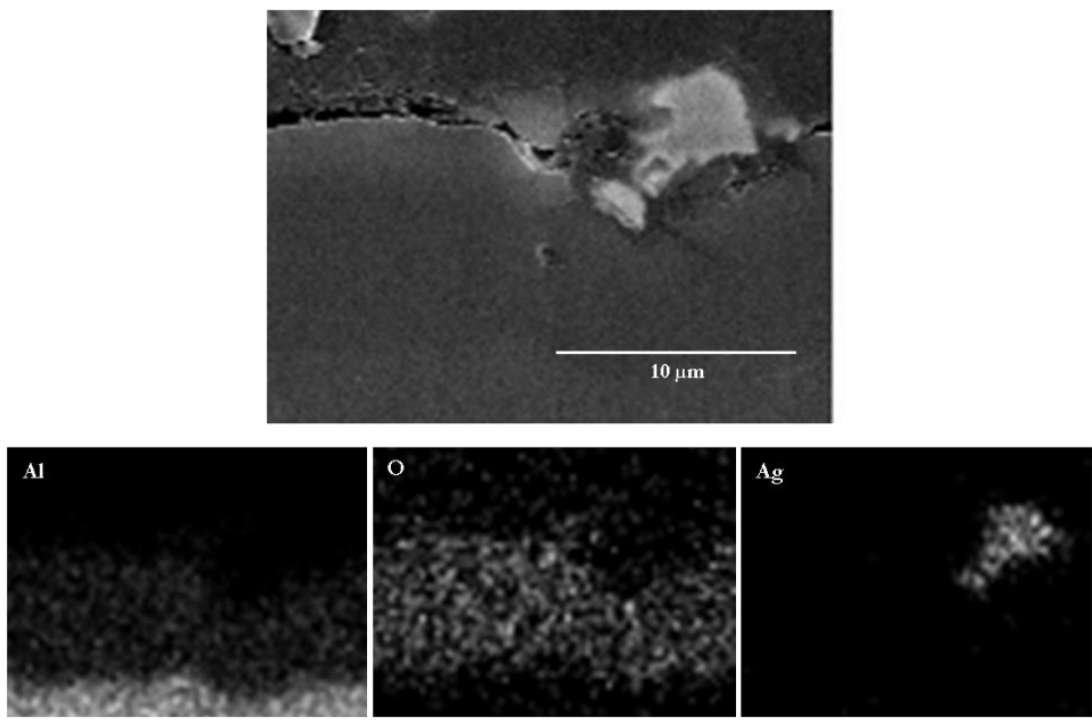

Fig. 6. EDS mapping analysis of the anodized AA6061-T6 with AgNPs deposition synthesized using $1 \mathrm{mM}$ $\mathrm{AgNO}_{3}$.

\subsection{Antibacterial Efficiency}

The measurements were carried out every month according to JIS Z 2801 for three months with $0.5 \mathrm{mM}$ and $1.0 \mathrm{mM} \mathrm{AgNO} 3$ solutions. Figures 7 and 8 display typical bacterial counted plates of gram-negative (E.coli) and gram-positive bacteria (S.aureus), respectively. Images of different dilution factors were illustrated depending on the number of colonies obtained in plates; it must be in a range of 30 to 300 colonies in order to be able to count by naked eyes. However, if the number of colonies in plates of all dilution factors was zero, the image of dilution factor of $10^{7}$ was displayed.

The number of counted colonies was used to calculate antibacterial activity (R-value) and percentage of reduction of bacteria as displayed in Table 2 and 3 for E.coli and S.aureus, respectively. R-value must be 2 or above and percentage of reduction must be $99 \%$ or above to be considered as having antibacterial property [16]. On the $0^{\text {th }}$ month, both $0.5 \mathrm{mM}$ and $1.0 \mathrm{mM} \mathrm{AgNO}_{3}$ solutions showed $100 \%$ reduction of both bacteria. After the $3^{\text {rd }}$ month, $100 \%$ reduction of S.aureus was still achieved for both concentrations, whereas $71.6 \%$ and $97.3 \%$ reduction of E.coli were obtained when using $0.5 \mathrm{mM}$ and $1 \mathrm{mM} \mathrm{AgNO}_{3}$, respectively. It is evident that amount of AgNPs released from the anodic oxide film decreased as a function of time. In addition, 
previous works $[17,18]$ reported that minimum inhibitory concentrations (MIC) of silver nanoparticle solutions to be able to inhibit visible growth of S.aureus and E.coli were $1.96 \mu \mathrm{g} / \mathrm{mL}$ and $16 \mu \mathrm{g} / \mathrm{mL}$, respectively. This means that concentration of AgNPs used to inhibit E.coli efficiently is higher than that of S.aureus. In this work, the decrease in \% reduction was also observed only in the case of E.Coli, especially at $0.5 \mathrm{mM}$. Moreover, differences in cell wall structure and thickness of peptidoglycan layer between grampositive and gram-negative bacteria were reported [19]. Gram-positive bacteria have thicker peptidodyglycan layer than that of gram-negative. Hence, bonding between siliver ions and peptidoglycan layer of grampositive bacteria is stronger [20]. Thus, an attachment of siliver ions on gram-positive bacteria is better than that of gram-negative bacteria. This leads to more damage on the cell respiratory of gram-positive bacteria. In other words, gram-positive bacteria are killed easier than gram-negative bacteria.
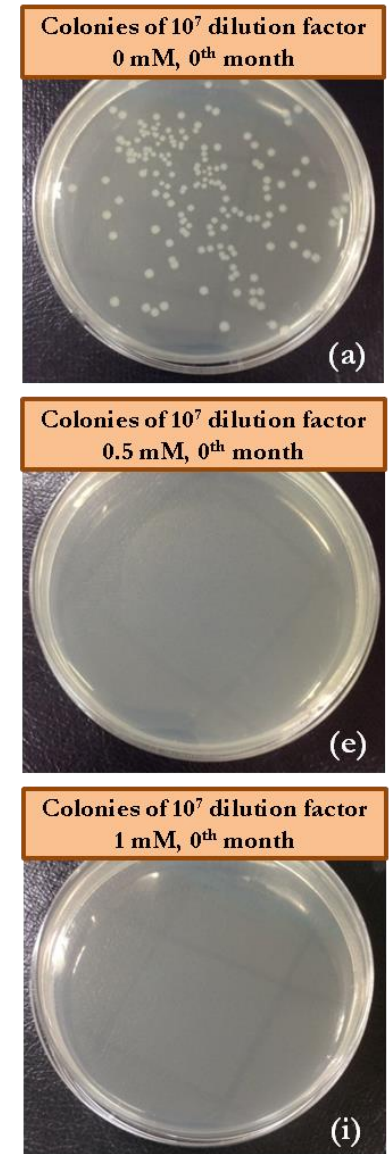
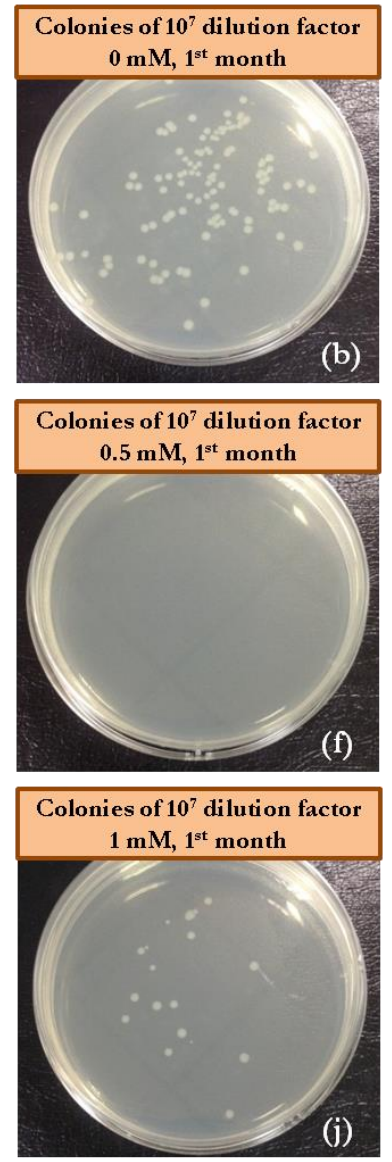
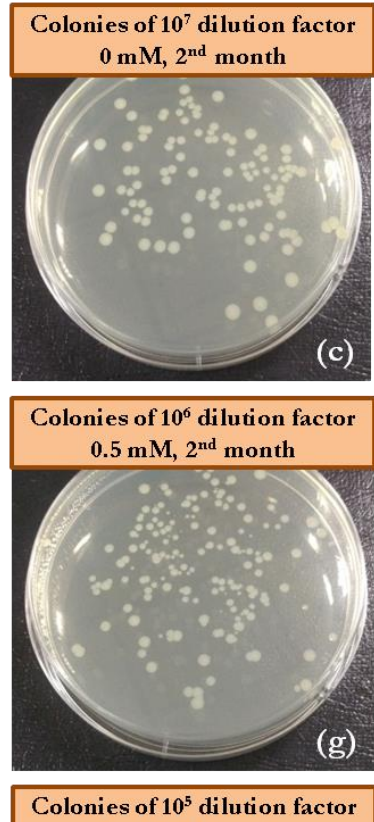
$1 \mathrm{mM}, 2^{\text {nd }}$ month

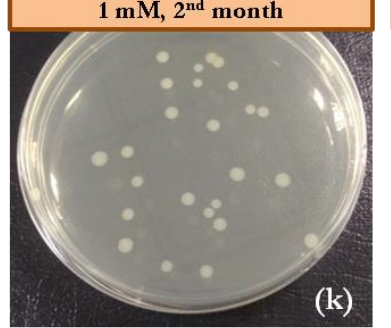

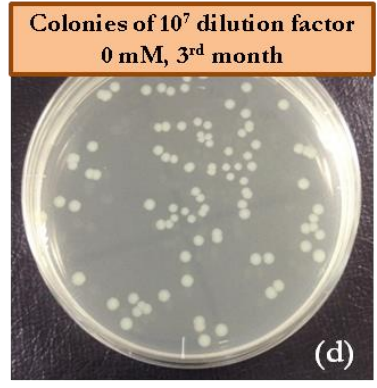
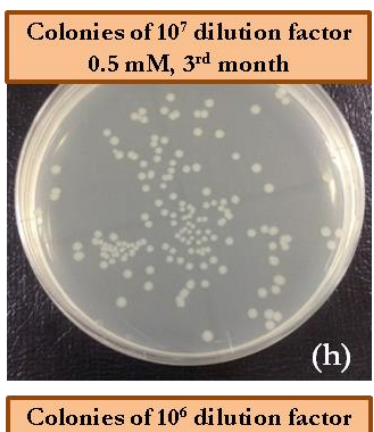
$1 \mathrm{mM}, 3^{\text {rd }}$ month

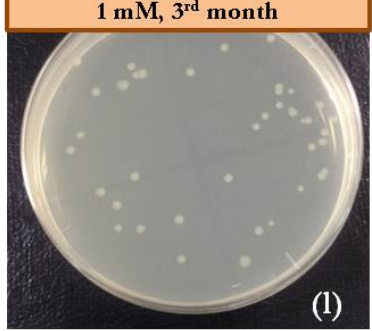

Fig. 7. Typical images of bacterial counted plates taken every month for three months of E.coli according to JIS Z 2801 standard test. (a) - (d) $0 \mathrm{mM} \mathrm{AgNO}_{3}$, (e) - (h) $0.5 \mathrm{mM} \mathrm{AgNO}_{3}$ and (i) - (l) $1 \mathrm{mM} \mathrm{AgNO}$. 

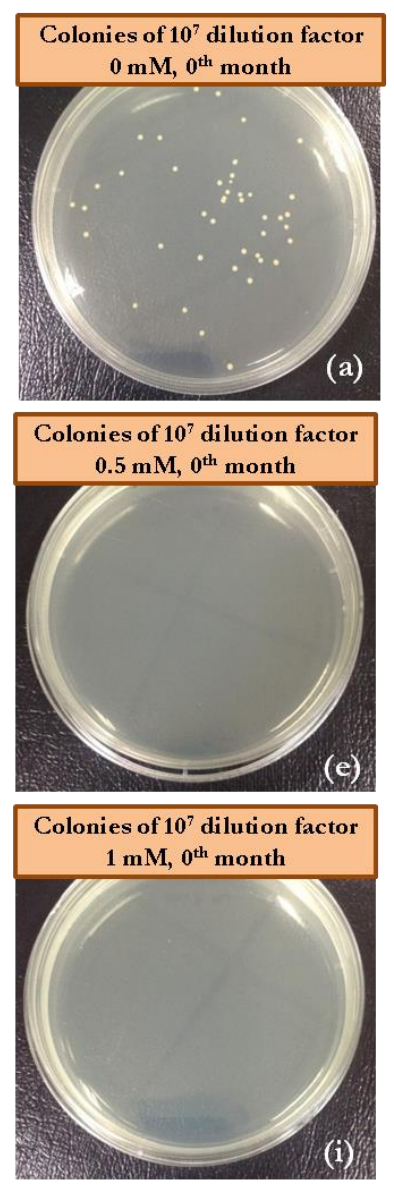
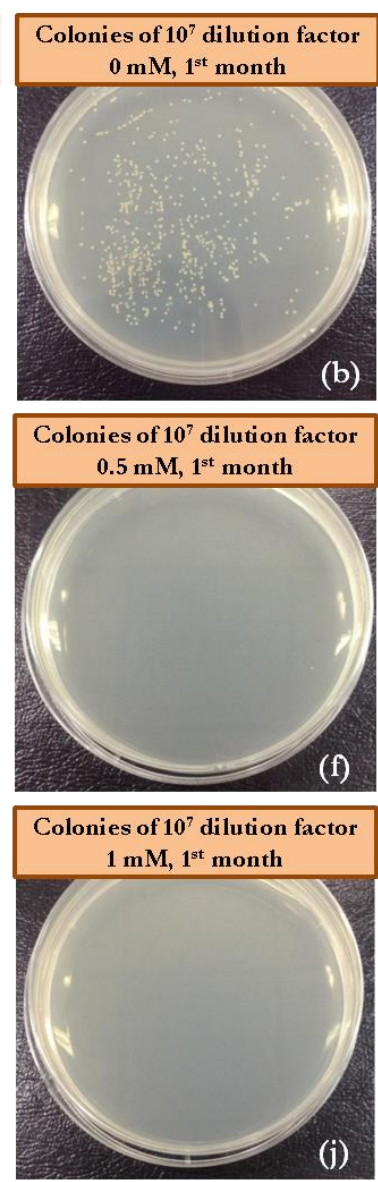
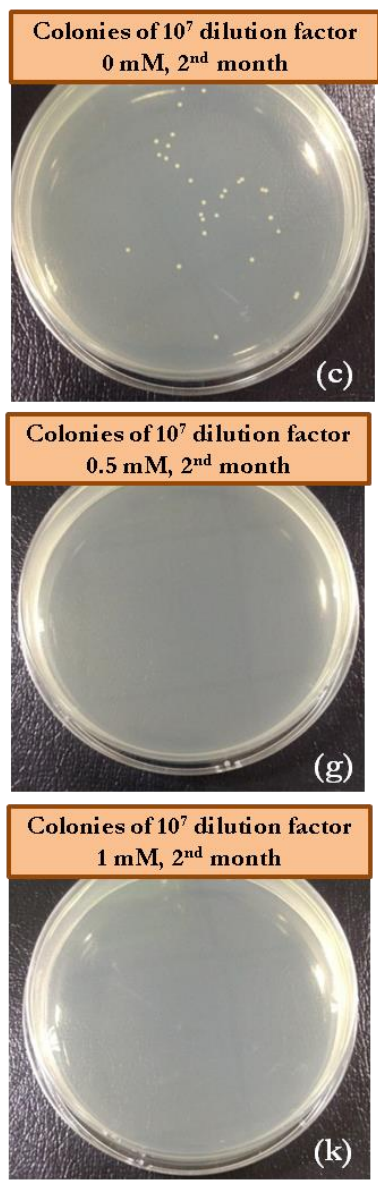
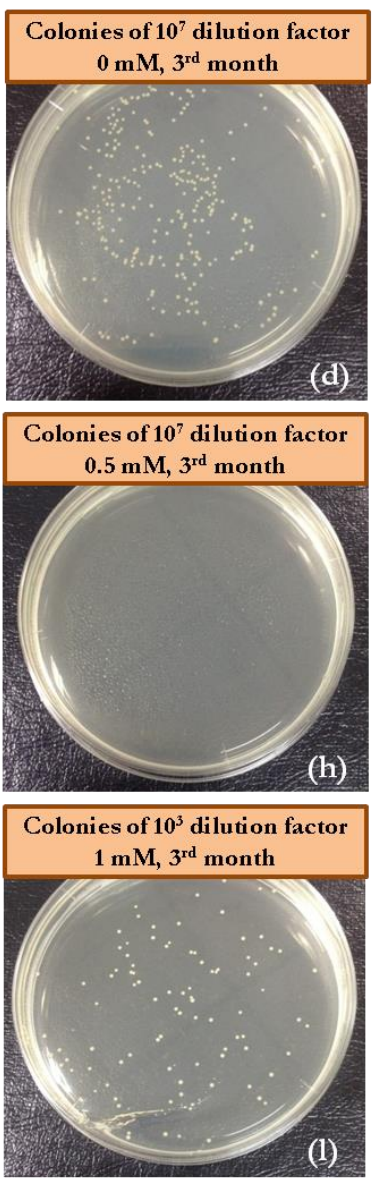

Fig. 8. Typical images of the bacterial counted plates taken every month for three months of S.aureus according to JIS Z 2801. (a) - (d) $0 \mathrm{mM} \mathrm{AgNO}_{3}$, (e) - (h) $0.5 \mathrm{mM} \mathrm{AgNO}_{3}$ and (i) - (l) $1 \mathrm{mM} \mathrm{AgNO}_{3}$.

Table 2. Antimicrobial activity and percentage of reduction of E.coli.

\begin{tabular}{lllll}
\hline $\begin{array}{l}\text { Concentraion } \\
\text { of } \text { AgNO }_{3}\end{array}$ & Month & $\begin{array}{l}\text { Average of viable cells } \\
\text { (Bacterial cells } / \mathbf{c m}^{2} \text { ) }\end{array}$ & $\begin{array}{l}\text { Antimicrobial } \\
\text { activity } \\
\text { (R-value) }\end{array}$ & $\begin{array}{l}\text { \% reduction of } \\
\text { E.coli }\end{array}$ \\
\hline $0 \mathrm{mM}$ & $0^{\text {th }}$ month & $4.27 \times 10^{9}$ & - & - \\
$($ Control $)$ & $1^{\text {st }}$ month & $3.38 \times 10^{9}$ & - & - \\
& $2^{\text {nd }}$ month & $2.64 \times 10^{9}$ & - & - \\
& $3^{\text {td }}$ month & $8.30 \times 10^{9}$ & - & - \\
$0.5 \mathrm{mM}$ & & & & \\
& $0^{\text {th }}$ month & 2.50 & 9.23 & 100.00 \\
& $1^{\text {st }}$ month & 2.50 & 9.13 & 100.00 \\
& $2^{\text {nd }}$ month & $5.92 \times 10^{7}$ & 1.65 & 97.76 \\
& $3^{\text {rd }}$ month & $2.35 \times 10^{9}$ & 0.55 & 71.64 \\
& & & & \\
& & & 9.23 & 100.00 \\
& $0^{\text {th }}$ month & 2.50 & 3.35 & 99.96 \\
& $1^{\text {st }}$ month & $1.50 \times 10^{6}$ & 2.92 & 99.88 \\
& $2^{\text {nd }}$ month & $3.17 \times 10^{6}$ & 1.56 & 97.27 \\
\hline
\end{tabular}


Table 3. Antimicrobial activity and percentage of reduction of S.aureus.

\begin{tabular}{lllll}
\hline $\begin{array}{l}\text { Concentraion } \\
\text { of } \mathbf{A g N O}_{3}\end{array}$ & Month & $\begin{array}{l}\text { Average of viable } \\
\text { cells } \\
\left.\text { (Bacterial cells } / \mathbf{c m}^{2}\right)\end{array}$ & $\begin{array}{l}\text { Antimicrobial } \\
\text { activity } \\
\text { (R-value) }\end{array}$ & $\begin{array}{l}\text { \% reduction } \\
\text { of } \text { S.aureus }\end{array}$ \\
\hline $0 \mathrm{mM}$ & $0^{\text {th }}$ month & $2.92 \times 10^{9}$ & - & - \\
$($ Control $)$ & $1^{\text {st }}$ month & $1.02 \times 10^{9}$ & - & - \\
& $2^{\text {nd }}$ month & $2.58 \times 10^{9}$ & - & - \\
& $3^{\text {td }}$ month & $4.12 \times 10^{9}$ & - & - \\
& & & & \\
$0.5 \mathrm{mM}$ & $0^{\text {th }}$ month & 2.50 & 9.07 & 100.00 \\
& $1^{\text {st }}$ month & 2.50 & 8.61 & 100.00 \\
& $2^{\text {nd }}$ month & 2.50 & 9.01 & 100.00 \\
& $3^{\text {td }}$ month & 2.50 & 9.22 & 100.00 \\
$1 \mathrm{mM}$ & & & & \\
& $0^{\text {th }}$ month & 2.50 & 9.07 & 100.00 \\
& $1^{\text {st }}$ month & 2.50 & 8.61 & 100.00 \\
& $2^{\text {nd }}$ month & 2.50 & 9.01 & 100.00 \\
& $3^{\text {td }}$ month & $1.83 \times 10^{5}$ & 4.35 & 100.00 \\
\hline
\end{tabular}

\subsection{Electrochemical Measurement}

Figure 9 shows potentiodynamic polarization curves of bare AA6061-T6, anodized AA6061-T6 without and with AgNPs deposition synthesized using 0.5 and $1 \mathrm{mM} \mathrm{AgNO}$. Corrosion potentials and corrosion current densities are shown in Table 4. It was found that the anodized AA6061-T6 showed much better corrosion resistance than that of bare AA6061-T6 due to the anodic oxide film on the surface. The anodized AA6061T6 with AgNPs deposition for both cases resulted in shifting of corrosion potentials to more positive values. This result corresponds to previous works due to deposition of silver on the surface [21, 22]. Higher corrosion current density was observed with AgNPs deposition. This is likely due to a presence of "the discrete uncovered area" on the surface as illustrated in Fig. 4(b) and (c). Solution can accumulate in the deep uncovered surface leading to more corrosion susceptibility [23]. Increasing $\mathrm{AgNO}_{3}$ concentration did not affect corrosion reactivity. Figure 10 reveals corrosion morphology of the anodized AA6061-T6 after polarization measurements. Pitting corrosion was seen for all cases.

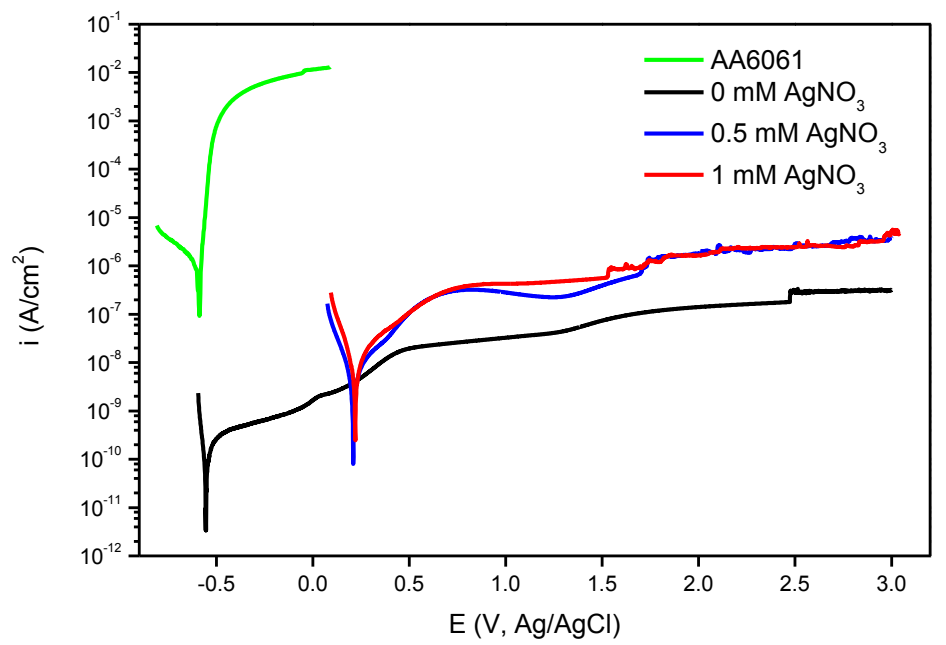

Fig. 9. Potentiodynamic polarization curves of bare AA6061-T6, anodized AA6061-T6 without and with

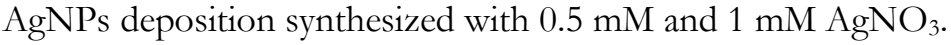


Table 4. A summary of corrosion potentials and corrosion current densities of bare AA6061-T6, anodized AA6061-T6 without and with AgNPs deposition.

\begin{tabular}{|c|c|c|}
\hline AA6061-T6 & $\begin{array}{l}\text { Corrosion potential } \\
\left(\mathrm{E}_{\text {corr }}\right) / \mathrm{mV}\end{array}$ & $\begin{array}{l}\text { Corrosion current } \\
\text { density }\left(\mathrm{I}_{\text {corr }}\right) / \mathrm{A} \mathrm{cm}^{-2}\end{array}$ \\
\hline Bare & $-592 \pm 5$ & $2.6 \pm 1.8 \times 10^{-6}$ \\
\hline $0 \mathrm{mM} \mathrm{AgNO} 3$ & $-529 \pm 81$ & $1.3 \pm 0.1 \times 10^{-10}$ \\
\hline $0.5 \mathrm{mM} \mathrm{AgNO}_{3}$ & $170 \pm 34$ & $5.7 \pm 3.3 \times 10^{-9}$ \\
\hline $1 \mathrm{mM} \mathrm{AgNO}_{3}$ & $207 \pm 43$ & $5.0 \pm 4.8 \times 10^{-9}$ \\
\hline
\end{tabular}
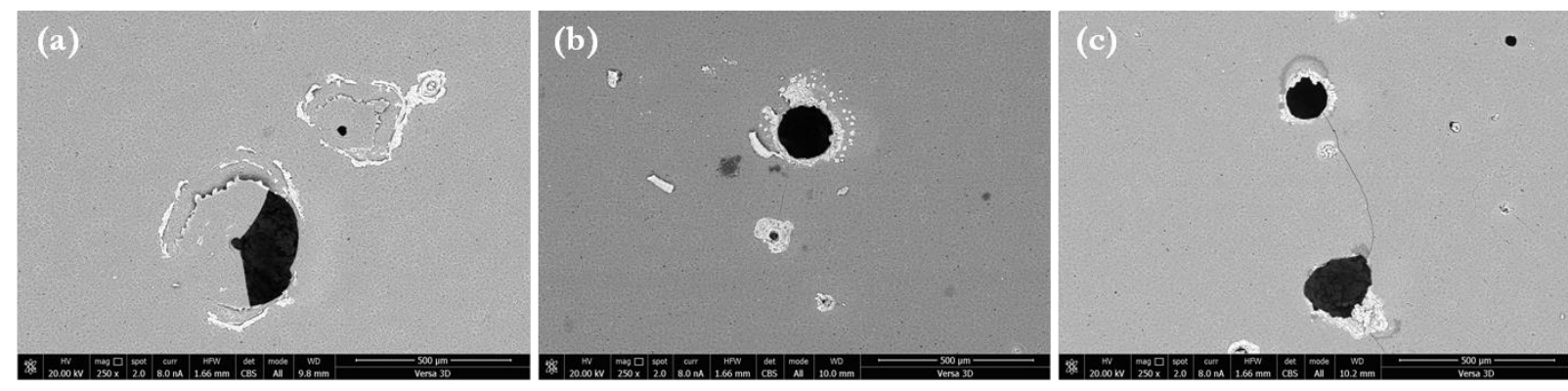

Fig. 10. FE-SEM images of the anodized AA6061-T6 after potentiodynamic polarization measurements. (a) $0 \mathrm{mM} \mathrm{AgNO}_{3}$, (b) $0.5 \mathrm{mM} \mathrm{AgNO}_{3}$ and (c) $1 \mathrm{mM} \mathrm{AgNO}_{3}$.

\section{Conclusions}

The anodized AA6061-T6 enhanced with antibacterial property was successfully produced. For S.aureus, increase in concentrations of $\mathrm{AgNO}_{3}$ used in this work showed no effect on antibacterial efficiency. $100 \%$ antibacterial efficiency was achieved. However, antibacterial efficiency of E.coli after exposure for three months decreased to $97.27 \%$ and $71.64 \%$ when using $\mathrm{AgNO}_{3}$ concentrations of $1 \mathrm{mM}$ and $0.5 \mathrm{mM}$, respectively. AgNPs showed slight adverse effect on corrosion resistance of the anodized AA6061-T6.

\section{Acknowledgement}

Authors would like to thank Faculty of Science, Mahidol University for Teaching Assistant Fellowship.

\section{References}

[1] S. Venukumar, B. Baby, S. Muthukumaran, and S. V. Kailas, "Microstructural and mechanical properties of walking friction stir spot welded AA 6061-T6 sheets," Procedia Mater. Sci., vol. 6, pp. 656-665, 2014.

[2] A. Dorbane, G. Ayoub, B. Mansoor, R. Hamade, G. Kridli, and A. Imad, "Observations of the mechanical response and evolution of damage of AA6061-T6 under different strain rates and temperatures," Mater. Sci. Eng., A, vol. 624, pp. 239-249, Jan. 2015.

[3] I. J. Polmear, "Wrought aluminium alloys," in Light Alloys: Metallurgy of the Light Metals, 3rd ed. London: Arnold, 1995, ch 3, pp. 92.

[4] X. Zhao, Y. Zuo, J. Zhao, J. Xiong, and Y. Tang, "A study on the self-sealing process of anodic films on aluminum by EIS,” Surf. Coat. Technol., vol. 200, no. 24, pp. 6846-6853, Aug. 2006.

[5] A. Hakimizad, K. Raeissi, and F. Ashrafizadeh, "A comparative study of corrosion performance of sealed anodized layers of conventionally colored and interference-colored aluminum," Surf. Coat. Technol., vol. 206, no. 22, pp. 4628-4633, Jun. 2012.

[6] E. Ghali, "Aluminum COATINGS: Description and testing," in Corrosion Resistance of Aluminum and Magnesium Alloys: Understanding, Performance, and Testing, 1st ed. New Jersey: John Wiley \& Sons, 2012, ch. 14, pp. 496-503.

[7] K. A. Yasakau, M. L. Zheludkevich, and M. G. S. Ferreira, "Role of intermetallics in corrosion of aluminum alloys. Smart corrosion protection," in Intermetallic Matrix Composites: Properties and Applications. Woodhead Publishing, 2018, ch. 15, pp. 425-462. 
[8] A. F. F. Giacobone, S. A. Rodriguez, A. L. Burkart, and R. A. Pizarro, "Microbiological induced corrosion of AA 6061 nuclear alloy in highly diluted media by Bacillus cereus RE 10," Int. Biodeterior. Biodegrad., vol. 65, no. 8, pp. 1161-1168, Dec. 2011.

[9] N. M. Huang, S. Radiman, H. N. Lim, P. S. Khiew, W. S. Chiu, K. H. Lee, A. Syahida, R. Hashim, and C. H. Chia, "Gamma-Ray assisted synthesis of silver nanoparticles in chitosan solution and the antibacterial properties," Chem. Eng. J., vol. 155, no. 1-2, pp. 499-507, Dec. 2009.

[10] A. Ghafari-Nazari, F. Moztarzadeh, S. M. Rabiee, T. Rajabloo, M. Mozafari, and L. Tayebi, "Antibacterial activity of silver photodeposited nepheline thin film coatings," Ceram. Int., vol. 38, no. 7, pp. 5445-5451, Sep. 2012.

[11] J. Lambert, M. Dumont, J. D. Cote, D. Rfvard, F. Paradis, S. Arsenault, and D. Gaudet, "Anodized metal product with antimicrobial properties and method for producing the same," WO 2013/155618 A1, Oct. 2013.

[12] T. R. Achiterhoff, K. H. Darcy, J. A. Nalewick, and L. W. Hodges, "Antimicrobial process on metal," US 2012/0186981 A1, Jul. 2011.

[13] L. D. nardo, G. Candiani, A. Cigada, D. Z. Michiei, and G. Zanchetta, "Method to obtain anodized aluminium surfaces with antibacterial properties," WO 2013/174502 A2, Nov. 2013.

[14] C. C. Lin and F. J. Lai, "Antimicrobal complex surface and method of fabricating the same," US 2015/0208662 A1, Jul. 2015.

[15] M. U. Rashid, Md. K. H. Bhuiyan, and M. E. Quayum, "Synthesis of silver nano particles (Ag-NPs) and their uses for quantitative analysis of vitamin C tablets," Dhaka Univ. J. Pharm. Sci., vol. 12, no. 1, pp. 29-33, Jun. 2013.

[16] Antibacterial Products—Test for Antibacterial Activity and Efficacy, JIS Z 2801, 2010.

[17] A. F. Wady, A. L. Machado, C. C. Foggi, C. A. Zamperini, V. Zucolotto, E. B. Moffa, and C. E. vergani, "Effect of silver nanoparticles solution on Staphylococcus aureus and Candida spp.," J. Nanomater., vol. 2014, 2014.

[18] A. K. Keshari, R. Srivastava, P. Singh, V. B. Yadav, and G. Nath, "Antioxidant and antibacterial activity of silver nanoparticles synthesized by Cestrum nocturnum," J. Ayurveda. Integr. Med., Aug. 2018.

[19] N. Malanovic and K. Lohner, "Gram-positive bacterial cell envelopes: The impact on the activity of antimicrobial peptides," Biochim. Biophys. Acta., vol. 1858, no. 5, pp. 936-946, May 2016.

[20] P. V. Viet, T. T. Sang, N. H. N. Bich, and C. M. Thi, "An improved green synthesis method and Escherichia coli antibacterial activity of silver nanoparticles," J. Photochem. Photobiol. B, Biol., vol. 182, pp. 108-114, May 2018.

[21] Q. Cai, S. Li, J. Pu, X. Bai, H. Wang, Z. Cai, and X. Wang, "Corrosion resistance and antifouling activities of silver-doped CrN coatings deposited by magnetron sputtering," Surf. Coat. Technol., vol. 354, pp. 194202, Nov. 2018.

[22] Ch. Girginov, S. Kozhukharov, D. Kiradzhiyska, and R. Mancheva, "Characterization of porous anodic alumima with AC-incorporated silver," Electrochim. Acta, vol. 292, pp. 614-627, Dec. 2018.

[23] M. Mehdizade, M. Soltanieh, and A. R. Eivani, "Investigation of anodizing time and pulse voltage modes on the corrosion behavior of nanostructured anodic layer in commercial pure aluminum," Surf. Coat. Technol., vol. 358, pp. 741-752, Jan. 2019. 